\title{
Study on Weak Soil Improvement by Using Geopolymer and Paper Fragments
}

\author{
Minh Chien VU*, Tomoaki SATOMI*, Hiroshi TAKAHASHI ${ }^{\star}$ and Anh Tuan LE** \\ ${ }^{*}$ Graduate School of Environmental Studies, Tohoku University, Sendai 980-8579, Japan \\ ** Faculty of Civil Engineering, Bach Khoa University, Ho Chi Minh, Viet Nam \\ E-mail:chien.minh.vu.p5@dc.tohoku.ac.jp
}

\begin{abstract}
Landslide or landslip is one of the natural disasters which is unfortunately unavoidable. We have already established the Fiber-Cement-Stabilized Soil Method that can improve the weak soil of actual landslide areas engendered from an earthquake or heavy rainfall by using paper fragments and cement. However, nowadays, the cost of fiber (paper debris) is tending to increase and Portland cement is not environmentally friendly cementitious material for sustainable development. In this research, Geopolymer which expects to modify soft soil (sludge) at low degree Celsius condition and reduces amount additive of fiber is executed. The process of Geopolymerization involving the silicates and aluminates exacted from by-products is contemplated as a mature and cost-effective solution to many problems where hazardous residue has to be treated and stored under critical environmental conditions. This paper presents the details of the study carried out on the characteristic of sludge improved Fiber-Geopolymer-Stabilized Soil Method. The composition of imitation sludge was $60 \%$ silt, $40 \%$ clay and $70 \%$ water content. Sodium hydroxide $(\mathrm{NaOH}) 12$ Molar and sodium silicate solution $\left(\mathrm{Na}_{2} \mathrm{SiO}_{3}\right)$ were prepared. The test specimens were made of $50 \mathrm{x} 100 \mathrm{~mm}$ cylindrical mold and $20^{\circ} \mathrm{C}$ temperature curing condition. The result of modified sludge shows the improvement in strength, strain and high durability with drying and wetting tests regardless of the increase in experimenting rounds.
\end{abstract}

Keywords : Sludge, Fiber-Geopolymer-Stabilized soil, drying - wetting test, durability, failure strength, failure strain

\section{INTRODUCTION}

A landslide has considerable impact, causing structural damage and loss of life. The landslide disaster occurs frequently for complex natural condition and becomes a major factor hindering the social and economic development in loess regions. The incidences of landslides have been increasing in recent years due to the rapid pace of developments in hilly regions and climate change Ref. [1]. Furthermore, Japan is known as the nation that suffered huge damage by earthquake and seismic activity. The occurrence of earthquakes in steep landslide-prone areas greatly increases the possibilities of landslides due to ground shaking solely or shaking caused dilation of soil materials which allows rapid infiltration of water. Moreover, landslide generates a huge volume of sludge that blocks road, supply lines (telecommunication, electricity, water, etc.) and waterways. Under the need of recovery, improvement of sludge generated in disaster site is required.

In our laboratory, Portland cement was predominantly used as adhesive to improve the characteristic of sludge. Undoubtedly, it owns many advantages but a new binder which is proposed to reduce greenhouse gas emissions should be considered. Ordinary Portland Cement (OPC) is most popular adhesive in construction globally. The cement industry is known as high embodied energy, with carbon dioxide equivalent $\left(\mathrm{CO}_{2}-\mathrm{e}\right)$ ranging from 0.66 to $0.82 \mathrm{~kg}$ of $\mathrm{CO}_{2}$ emitted for every kilogram manufactured Refs [2$4]$. Due to the exponential use of concrete, cement production has increased at a much higher speed than atmospheric $\mathrm{CO}_{2}$ concentration, i.e. all major $\mathrm{CO}_{2}$ emission caused by human activities, such as energy and transportation. Thus, to overcome this issue, a new technology should be innovated to decrease adverse impact to environment or civil engineering industry, or to research alternative binder to substitute or supplement Portland cement.

An alternative cementitious binder, termed "geopolymer", comprising of an alkali-activated fly ash was created by J. Davidovits in 1979 which was described the chemical properties of inorganic polymers based on aluminosilicates Ref. [5]. Geopolymers (Geo) can be synthesized from inorganic materials rich in silicon ( $\mathrm{Si}$ ) and Aluminium (Al) materials Refs [6,7] such as metakaolin, steel furnace slag and fly ash that reacts with alkaline activators to become cementitious. Alkaline activators used for geopolymers are usually a combination of a hydroxyl, usually sodium hydroxide $(\mathrm{NaOH})$ or potassium hydroxide $(\mathrm{KOH})$, and a glassy silicate $\left(\mathrm{Na}_{2} \mathrm{SiO}_{3}\right)$ Refs $[7,8]$. Generally, sodium hydroxide was used with sodium silicate because of low cost, availability and the ability to stabilize silicate monomers and dimers present in solution. Geopolymers have been the subject of intense study because they are environmentally friendly cementing agents with low energy consumption, low toxicity, and are stable at high temperature as well as have high durability Refs $[9,10]$. By the way, we have already developed a new recycling method for high water content mud such as construction sludge by using paper debris (fragments of old newspaper) and cement to increase the 
recycling rate of construction sludge Ref. [11]. Literally, this method is called "Fiber-cement-stabilized soil method (FCSS)". Modified-soil produced by this method has several features such as high failure strength and failure strain, high durability for drying and wetting as well as high dynamic strength Ref. [12]. However, this method utilizes the cement with high embodied energy binder. If geopolymers can be used instead of cement, this will become a great advantage because of their durability and environmentally friendly characteristic. However, the application of geopolymers for the fiber-cement-stabilized method has not been examined yet. Therefore, in this study, the influence of geopolymers on failure strength, failure strain and durability of modified sludge are investigated. In order to distinguish with the previous method (FCSS), the method by using geopolymer is called "Fibergeopolymer-stabilized soil method (FGSS)".

\section{MATERIALS AND EXPERIMENTAL PROCEDURE}

\subsection{Materials}

The imitation sludge was made by mixing of Kasaoka clay (Kasanen Kogyo Company) and silt (Marunaka Shirato Company). The mass ratio of silt and clay is $3: 2$, the grain size distribution of imitation sludge and 2 samples which obtained in landslide area was shown in Figure 1. Physical and mechanical properties of imitation sludge were shown in Table 1. Fly ash (FA), from Tohoku Hatsuden Kogyo Company, was used as the main source of aluminosilicate material for making geopolymer cement. The amount of $\mathrm{CaO}$ in fly ash is $5.51 \%$, therefore, it is classified as Class F according to ASTM C 618 Ref. [13]. Table 2 shows Chemical composition of clay, silt and fly ash. A mixture of sodium hydroxide $(\mathrm{NaOH})$ and sodium silicate $\left(\mathrm{Na}_{2} \mathrm{SiO}_{3}\right)$ solution was used as the alkaline activator solution (AA). Sodium hydroxide ( $\mathrm{SH}$ ) and Sodium silicate (SS) were collected from a local commercial producer. The concentration of sodium hydroxide solution was kept constantly at 12 molars for all mixtures. The mass ratio of $\mathrm{SiO}_{2}$ to $\mathrm{Na}_{2} \mathrm{O}$ of sodium silicate was 3 with chemical compositions of

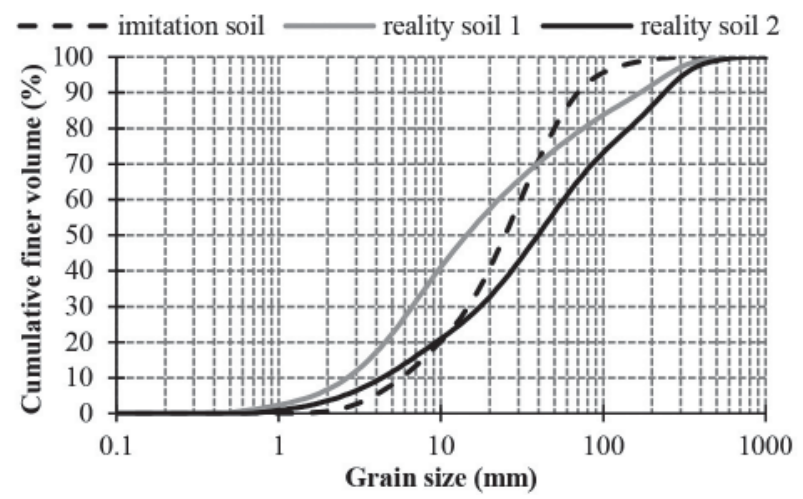

Figure 1 Grain size distribution of imitation sludge and reality sludge

Table 1 Physical and mechanical properties of sludge

\begin{tabular}{lcc}
\hline Property & Value & Unit \\
\hline D50 & 17.2 & {$[\mu \mathrm{m}]$} \\
Particle density & 2467.1 & {$\left[\mathrm{~kg} / \mathrm{m}^{3}\right]$} \\
Liquid limit (LL) & 46.1 & {$[\%]$} \\
Plastic limit (PL) & 29.4 & {$[\%]$} \\
Plastic index (PI) & 16.7 & {$[\%]$} \\
\hline
\end{tabular}

Table 2 Chemical composition of silt, clay, and fly ash

\begin{tabular}{cccc}
\hline Sample & Silt & Clay & Fly ash \\
\hline $\mathrm{SiO}_{2}$ & 77.85 & 69.07 & 58.8 \\
$\mathrm{Al}_{2} \mathrm{O}_{3}$ & 12.88 & 20.22 & 24.9 \\
$\mathrm{Fe}_{2} \mathrm{O}_{3}$ & 2.08 & 5.46 & 5.35 \\
$\mathrm{CaO}$ & 1.88 & 0.91 & 5.51 \\
$\mathrm{MgO}$ & 0.28 & 0.81 & 1.44 \\
$\mathrm{MnO}$ & 0.072 & 0.027 & 0.05 \\
$\mathrm{Na}_{2} \mathrm{O}$ & 1.97 & 1.48 & 1.16 \\
$\mathrm{~K}_{2} \mathrm{O}$ & 2.42 & 2.75 & 1.34 \\
\hline
\end{tabular}

Table 3 Mixing condition

\begin{tabular}{cccccc}
\hline $\begin{array}{c}\text { Specimen } \\
\text { No. }\end{array}$ & $\begin{array}{c}\text { Water } \\
\text { Content } \\
(\%)\end{array}$ & AA:FA & SS:SH & $\begin{array}{c}\text { Paper } \\
\text { debris } \\
\left(\mathrm{kg} / \mathrm{m}^{3}\right)\end{array}$ & $\begin{array}{c}\text { Geo } \\
(\%)\end{array}$ \\
\hline G0 & 70 & $2: 5$ & $7: 3$ & 0 & 30 \\
G1 & 70 & $2: 5$ & $7: 3$ & 10 & 30 \\
G2 & 70 & $2: 5$ & $7: 3$ & 20 & 30 \\
G3 & 70 & $2: 5$ & $7: 3$ & 30 & 30 \\
\hline
\end{tabular}

$29.53 \%$ of $\mathrm{SiO}_{2}, 10.56 \%$ of $\mathrm{Na}_{2} \mathrm{O}$ and $59.91 \%$ water. The density of SH and SS is 1.5 and 1.35 , respectively.

\subsection{Procedure of preparing the specimens}

Firsts, clay, and silt were prepared at the ratio of $2: 3$ and they were mixed with water ( $70 \%$ by weight of dry soil) for 5 minutes by a mixer. Then, fly ash and alkaline activator solution were poured gradually in the mixer and the mixing was continued for further 8-10 minutes to achieve a uniform mixing. After that, paper debris was added and mixed further 5 minutes. The modifiedsludge, which was carefully put into the oven, was cured at $20 \pm$ 3 degrees Celsius for two days as initial curing. After the initial curing was over, specimens were made by compaction method using a cylindrical metal mold and were compacted with four layers of soil ( 5 times for the first layer, 10 times for the second layer, 10 times for the third layer, and 20 times for the final layer). These specimens were wrapped by vinyl sheet, cured at $20 \pm 3$ degrees Celsius and checking the strength properties as 7, 14, 28, 42 days. The durability of specimens after curing 28 and 42 days was measured. The mixing condition was shown in Table 3.

\subsection{Procedure of Drying - Wetting test}

Table 4 shows the procedures of cyclic test for drying and wetting based on final report of cooperative research developed by Ref. [14]. One test cycle consists of the drying in an electric furnace for 2 days at 40 degrees Celsius and the wetting in water for 1 day at 20 degrees Celsius. Observation and taking photographs of specimens were undertaken after drying and wetting of each cycle, and the unconfined compressive test (wet compressive strength) was executed to investigate the impact of increasing the cycle number to the failure strength and strain. Soundness of specimens is estimated according to the rank shown in Table 5 . 
Table 4 Procedure of cyclic test for drying and wetting

\begin{tabular}{lll}
\hline Specimens & 1 cycle & Confirmation item \\
\hline & & *Unconfined \\
& $\begin{array}{l}\text { Drying for } \\
\text { two days at }\end{array}$ & $\begin{array}{l}\text { compression test after } \\
\text { prescribed cycle }(0 \text { th, }\end{array}$ \\
& $40^{\circ} \mathrm{C}$ and & 2nd, 4th, 6th, 8th, 10th) \\
wetting for & * Condition check and \\
& one day at & photography of \\
& $20^{\circ} \mathrm{C}$ & specimens after drying \\
& & and wetting of each \\
& & cycle \\
\hline
\end{tabular}

Table 5 Soundness of specimens

\begin{tabular}{|c|c|c|}
\hline Rank & Crack condition & Chasm condition \\
\hline A & \multicolumn{2}{|c|}{ Outwardly, there is no change } \\
\hline B & Appearance of fine crack & $\begin{array}{c}\text { Appearance of } \\
\text { surface delamination }\end{array}$ \\
\hline $\mathrm{C}$ & $\begin{array}{l}\text { Appearance of intelligible } \\
\text { crack in part of specimen }\end{array}$ & $\begin{array}{l}\text { Small chasm of } \\
\text { specimen }\end{array}$ \\
\hline $\mathrm{D}$ & $\begin{array}{l}\text { Appearance of intelligible } \\
\text { crack over specimen }\end{array}$ & $\begin{array}{l}\text { Great chasm of } \\
\text { specimen }\end{array}$ \\
\hline $\mathrm{E}$ & \multicolumn{2}{|c|}{ Falling of specimen $(\sim 20 \%)$} \\
\hline $\mathrm{F}$ & \multicolumn{2}{|c|}{$\begin{array}{c}\text { Specimen fall wholly, but shape of specimen is } \\
\text { remaining }\end{array}$} \\
\hline G & \multicolumn{2}{|c|}{ Specimen fall wholly, and fragment is aggregated } \\
\hline $\mathrm{H}$ & \multicolumn{2}{|c|}{ Specimen fall wholly, and fragment is muddy } \\
\hline
\end{tabular}

\section{EXPERIMENTAL RESULTS AND DISCUSSION}

\subsection{Evaluation of Fiber-Geopolymer-Stabilized soil method}

Prior to the unconfined compression tests, the target values for the failure strength and failure strain were set as follows Ref. [15]:

Failure strength: more than $125 \mathrm{kN} / \mathrm{m}^{2}$

Failure strain: more than 5\%.

Figure 2 and Figure 3 show the development failure strength and failure strain of modified sludge curing at $20^{\circ} \mathrm{C}$ following the procedure. In that case, the removal of heat treatment means that there was no acceleration of the hardening process of geopolymerization. Nevertheless, the geopolymer reactions could continue under ambient conditions for a long time after casting and until achieving an acceptable harden Ref. [16]. During that time,

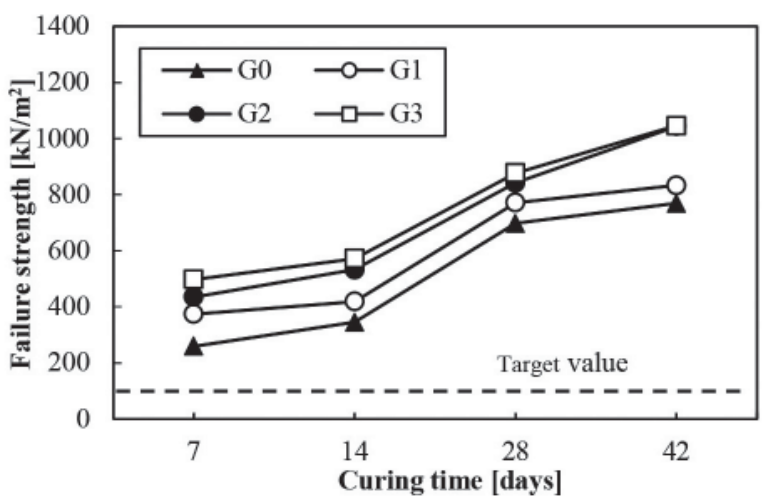

Figure 2 Relationship between paper content and failure strength development of modified sludge

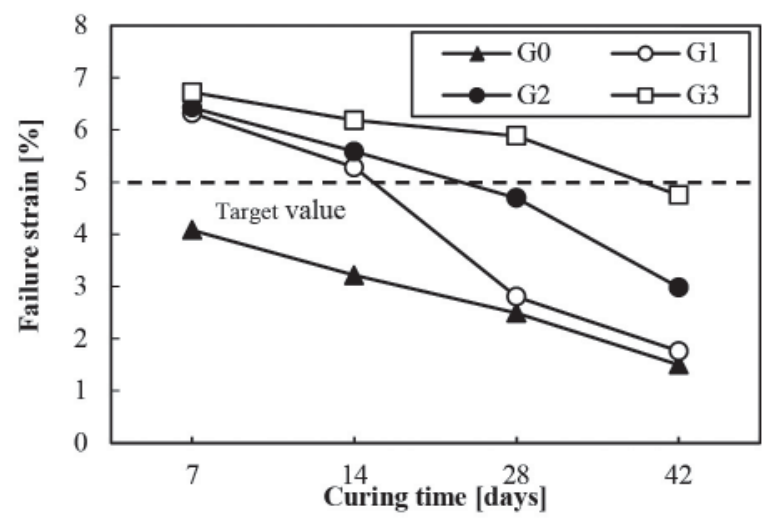

Figure 3 Relationship between paper content and failure strain development of modified sludge

the moisture effect might be a more significant factor to modified sludge.

Improving the rheology of the mixture by reducing water as it was done for the mixture G1, G2, G3 with a high amount of paper debris was found to increase the reactivity and favor unconfined compressive strength development. This trend is in line with other researches on the role of water in geopolymerization Refs [17-19]. The geopolymerization, based on the view of thermodynamics, can be approximately partitioned into two periods: (i) dissolutionhydrolysis, (ii) hydrolysis-polycondensation. In the (i) period, water is an indispensable reactant for the destruction of solid particles and the hydrolysis of dissolved $\mathrm{Al}^{3+}$ and $\mathrm{Si}^{4+}$ ions, both of which required abundant water at the beginning. If the $\mathrm{OH}-$ concentration is sufficiently high, increasing water will accelerate the dissolution and hydrolysis. The polycondensation kinetics could be interfered by excess water in this period resulting in smaller reactivity Refs [7,19], dilute the reaction or leach out the more soluble ions, and transport them away from the reaction zone. However, insufficient water leads to a bad wetting of the starting material and prevents the exposure alkali-activated fly ash. But in the period (ii), the main reaction may change from hydrolysis (consuming water) to polycondensation (releasing water). Water plays as a product in this period, if adding too much, will hinder the polycondensation kinetically. Therefore, water is, critical even in the final stages of geopolymerisation because it is needed as the transport medium and the polycondensation processes occur concomitantly with dissolution Refs $[19,20]$.

The test result Figure 2 shows that the failure strength of modified sludge increased slowly from 7-14 days meanwhile went up significantly from 14-28 days and slowed down from 28-42 days. The failure strain diminished steadily up to 42 days that was indicated in Figure 4. Mixture G1, G2, G3 achieved the strain target value after 14 days but only G3 obtained the expectation value after 28 and 42 days. The failure strength and failure strain also went up as increasing of paper debris content. This is possible because the absorption water of paper debris could make the lower moisture content, lead to a higher extent of the polycondensation reactions, and thus more produced geopolymers. Since the polycondensation reactions happen predominantly in the middle of the curing process and have been prolonged without the acceleration by heat in this research, it is expected that the moisture effect discussed above could play a more significant role. Moreover, the combination of low initial water content with low moisture conditions (wrapping 
specimens by vinyl sheet) during curing could improve ambientcured geopolymers and may produce strength results comparable to those of geopolymers that were heat treated Ref. [20].

\subsection{Evaluation of durability of modified sludge}

Figure 4 shows the relationship between degree soundness of specimen and cycle number. As for G0 without adding paper debris, specimens were destructed quickly by shrinkage when they immersed in water after $2^{\text {nd }}$ cycle test. Specimen G1 and G2 showed the good shape after $4^{\text {th }}$ cycle, but the soundness became worse after $5^{\text {th }}$ and $6^{\text {th }}$ cycle, respectively. Until $7^{\text {th }}$ and $9^{\text {th }}$ cycle, the intelligible crack outside of the G1 and G2 began to emerge. In contrary to this behavior, the soundness of G3 was not changed after $10^{\text {th }}$ cycle. This means that the connection between fine soil particles and geopolymer cement became stronger. In other word, the amount of paper debris in G1 and G2 is insufficient to preserve the durability of modified sludge, which resulted in the appearance of the crack by the drying-wetting cycles or the development strength of modified sludge is not adequate to suffer the harsh changing the temperature and environment condition test.

To have more evidence in demonstrating the predominant factor influencing the durability of modified sludge, the increasing of curing time was conducted, in particular, curing within 42 days. In the result, $\mathrm{G} 1, \mathrm{G} 2$, and $\mathrm{G} 3$ revealed the better shape of the specimen that indicated the in Figure 5. The soundness of specimen G1 showed the better result than the previous result until 7th cycle, fine cracks generated outside.

Specimens G2 and G3 did not change outwardly. Figure 6 and Figure 7 show the shape of specimens with different curing time after $10^{\text {th }}$ cycle test. It's clear to see that the intelligible crack appeared and the surface delaminated at specimens with lower amount of paper fragments and shorter time curing. In the contrast, the shape didn' $t$ change and the durability revealed high performance with the specimen with enough paper inside and curing term.

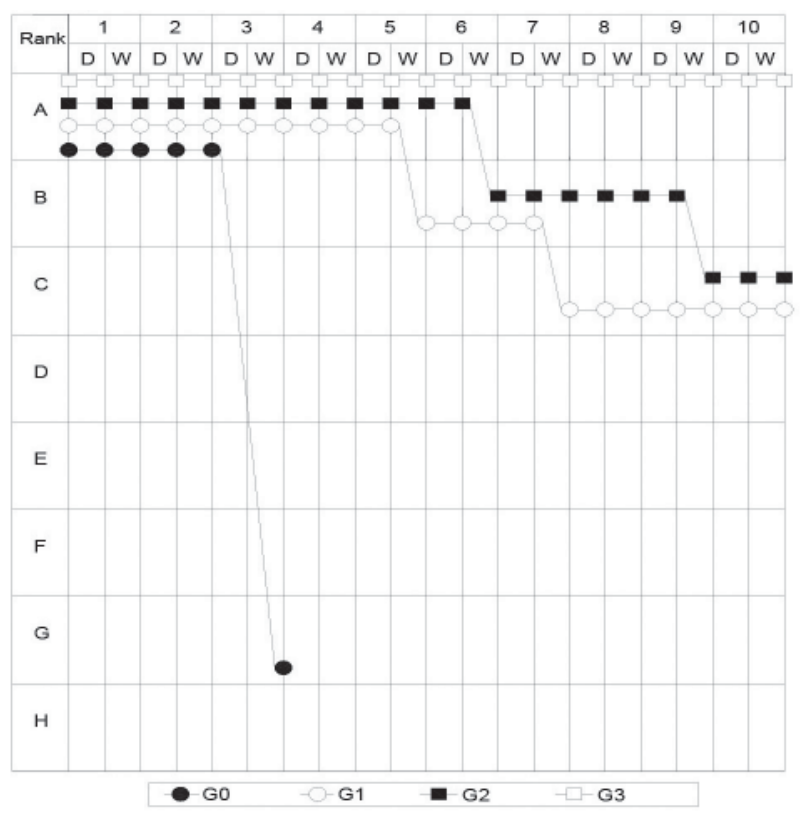

Figure 4 Soundness of specimens with cycle number (modified sludge after curing 28 days)

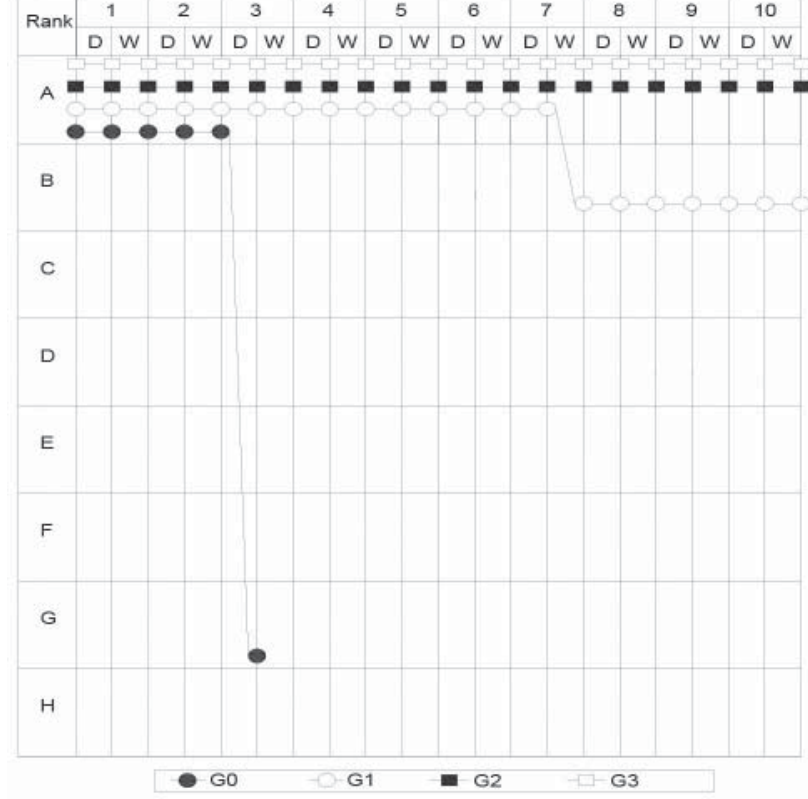

Figure 5 Soundness of specimens with cycle number (modified sludge after curing 42 days)

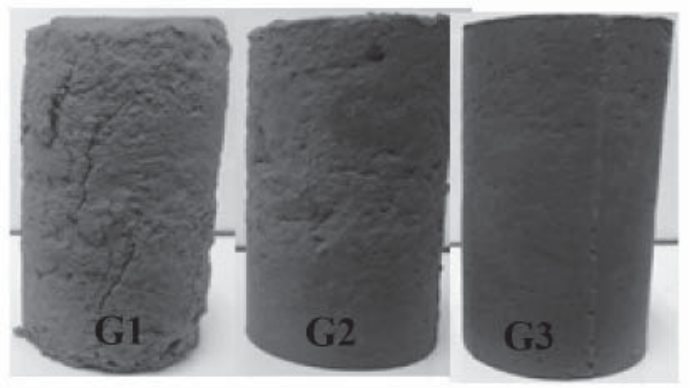

Figure 6 Specimens after $10^{\text {th }}$ cycle (After curing 28 days)

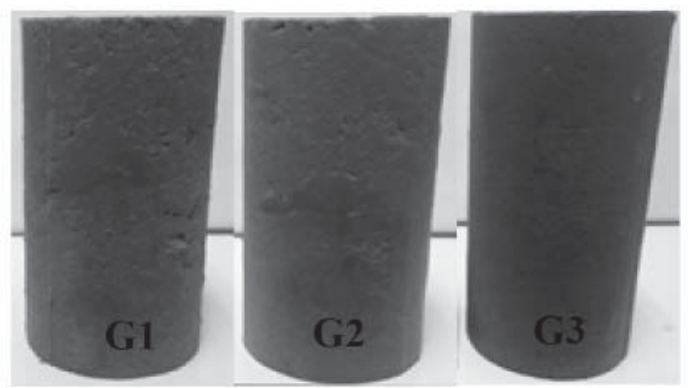

Figure 7 Specimens after $10^{\text {th }}$ cycle (After curing 42 days)

Figure 8 and Figure 9 show the relationship between cycle number and failure strength, the strain of modified sludge curing at 28 days. Failure strength of G0, G1, and G2 reduced significantly from $0-4$ cycles. On the contrary, specimen G3 didn't change the failure strength after 2 cycles but after 4 cycles, the strength was significantly deteriorated. From 4 th cycle to 10 th cycle, failure strength of G1 and G2 decreased considerably meanwhile G3 remained stable at around $700 \mathrm{~N} / \mathrm{m}^{2}$. At the beginning, the failure strength of all samples is significantly higher than the target value. But after 10 cycles, only G2 and G3 satisfy the target value, 


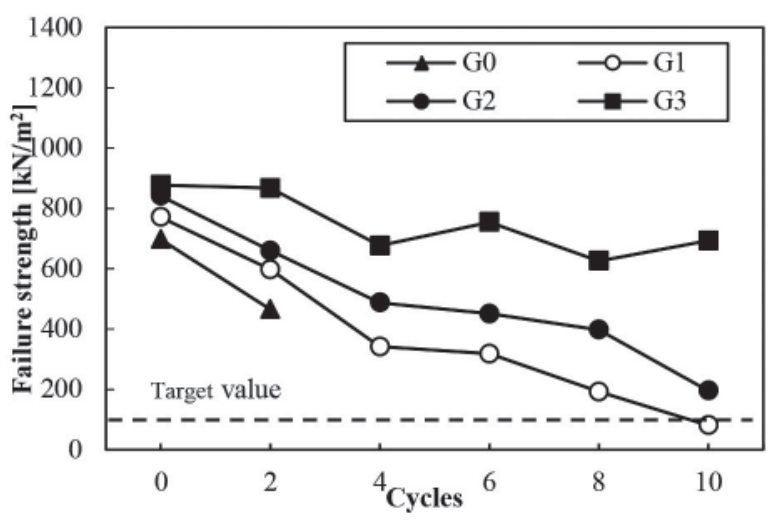

Figure 8 Relationship between cycle number and failure strength of modified sludge (after curing 28 days)

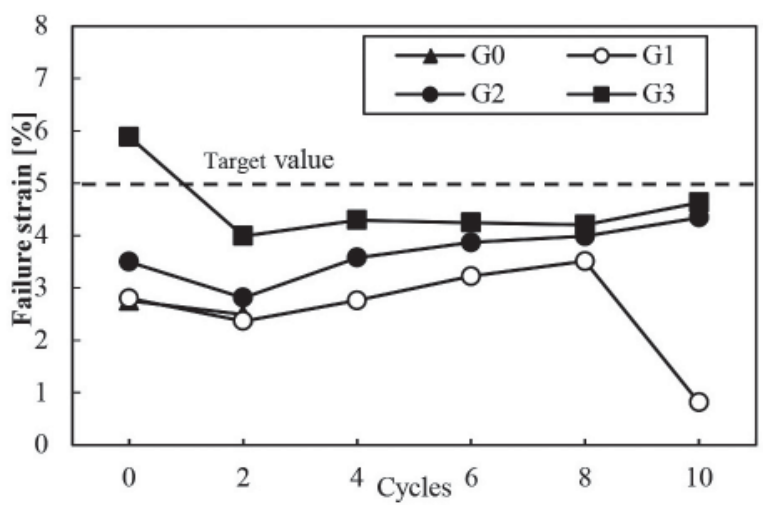

Figure 9 Relationship between cycle number and failure strain of modified sludge (after curing 28 days)

especially, it implies that $\mathrm{G} 3$ can be achieved acceptable value even smaller the additive amount of geopolymer. Normally, these values of failure strength of modified sludge decrease after immersion in water overnight at $200^{\circ} \mathrm{C}$ and recovered partly when the samples are dried at $400^{\circ} \mathrm{C}$. It is well known that this behavior is linked to the hydration of some $\mathrm{Si}-\mathrm{O}-\mathrm{Si}, \mathrm{Al}-\mathrm{O}-\mathrm{Al}$ and $\mathrm{Si}-\mathrm{O}-\mathrm{Al}$ bonds into $\mathrm{Si}-\mathrm{OH}$ and $\mathrm{Al}-\mathrm{OH}$ bonds in the geopolymer matrix, leading to a weakening of the structure Ref. $[18,20]$. But the increasing the amount of paper debris in agreement with the increasing water penetration of specimens, cause the high value of water absorption capacity of paper debris (nearly 5 times its mass), that leads to reduce the excess water for hydrating aluminosilicate bonds and inhibit partially this phenomenon. The other reason is the specimens with a high amount of paper debris will have superior porosity than the other ones. Generally, if the porosity in the specimen is large, this specimen is durable for drying and wetting because the porosity may act as a buffer for expanding in wetting and thinking in drying.

On the other hand, the influence of durability test also resulted in the failure strain of modified sludge. The failure strain of G0, $\mathrm{G} 1, \mathrm{G} 2$, and $\mathrm{G} 3$ declined from $0^{\text {th }}$ to $2^{\text {nd }}$ cycle but from $2^{\text {nd }}$ cycle to $10^{\text {th }}$ cycle, the failure strain went up. However, the failure strain of G1 decreased at 10th cycle because the specimen was extremely soft. The sense that led to this trend is from $0^{\text {th }}$ to $2^{\text {nd }}$ cycle, a lot amount of geopolymer structure was destructed by harsh durability test. From $2^{\text {nd }}$ cycle to $10^{\text {th }}$ cycle, this destruction was diminished

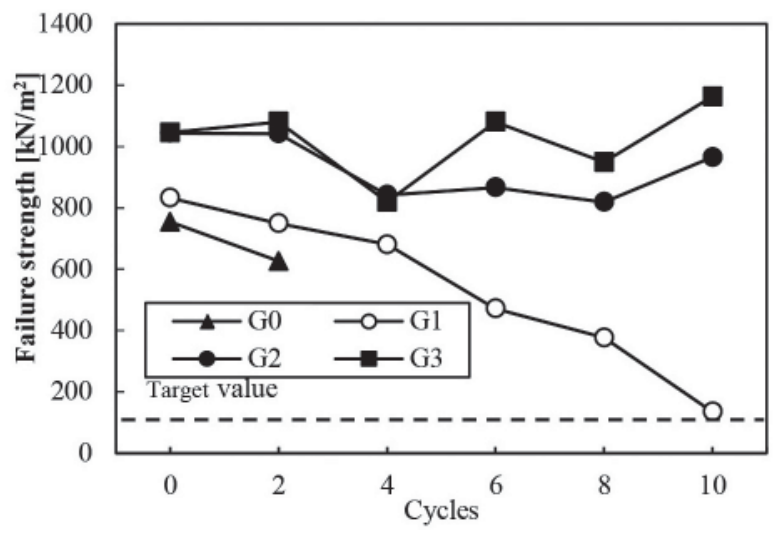

Figure 10 Relationship between cycle number and failure strength of modified sludge (after curing 42 days)

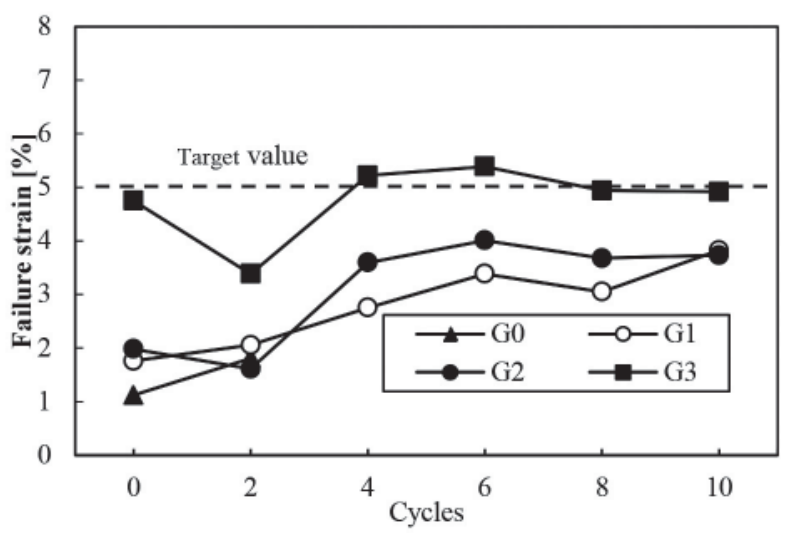

Figure 11 Relationship between cycle number and failure strain of modified sludge (after curing 42 days)

because the weak geopolymer chain had already demolished, only the strong chains could suffer. Beside of that, due to the destruction of geopolymer chains, water could easily penetrate into the fiber and lead the specimen softly. Fiber has two main roles in this method: first is inhibiting the destruction of geopolymer matrix among the durability test, second is improving the connection between soil particles and geopolymer structure. So that, G0 was destroyed after $2^{\text {nd }}$ cycle and G1 was nearly destroyed after $10^{\text {th }}$ cycle cause lower percentage amount of fibers. The additive amount of fiber increases this means the connection between the geopolymer structure and soil particles will be grown up. It resulted in the failure strain of all mixtures despite under the target value, fiber could preserve the strength of modified sludge through the extreme condition test. The curing time was also considered. Figure 10 and Figure 11 show the relationship between cycle number and failure strength, the strain of modified sludge curing at 42 days. The failure strength was improved as well as the durability of modified sludge. With the same behavior of previous curing time but after 4th cycle, the failure strength became stably in G2 and G3. Furthermore, the failure strain of G3 can achieve the target value. According to these results, we can conclude that not only the amount of paper debris is the important factor to improve the durability of modified sludge by using FGSS, but also the curing time is influential contribution on the performance of modified 
sludge.

\section{CONCLUSIONS}

This research investigated the failure strength, failure strain and durability of sludge improved by Fiber-Geopolymer-Stabilized soil method with different curing condition. The following results were obtained:

1) The increasing the additive amount of paper debris is increasing failure strength and failure strain of modified sludge. With the amount of paper debris is at $30 \mathrm{~kg} / \mathrm{m}^{3}$, failure strain achieved the target after 28 days, but after 42 days the strain reduced a little bit. With lower additive paper fragment, failure strain is lower than the target value. Failure strength of all specimens is significantly higher than the target value.

2) Curing time is the one of the most important factor that influences the durability of modified sludge. For the specimens curing 28 days, the amount of paper debris should be $30 \mathrm{~kg} / \mathrm{m}^{3}$ to achieve the target value after 10 cycles of Wetting-Drying test. After curing 42 days, specimens with 20 and $30 \mathrm{~kg} / \mathrm{m}^{3}$ show the high performance under 10 cycles test. It implies that the amount of paper fragment for improving the weak sludge can be reduced if the curing time is increasing. The influence of increasing additive amount of paper fragment to shorten the curing time will be considered in the future.

\section{AKNOWLEDGEMENT}

A part of this study was financially supported by KAKENHI [25289330]. We would like to gratefully appreciate this financial support.

\section{References}

[1] Göransson, G. I., D. Bendz and P. M. Larson, "Combining landslide and contaminant risk: a preliminary assessment." Journal of Soils and Sediments 9(1), 33-45 (2008).

[2] Habert, G., J. B. d'Espinose de Lacaillerie and N. Roussel, "An environmental evaluation of geopolymer based concrete production: reviewing current research trends." Journal of Cleaner Production 19(11), 1229-1238 (2011).

[3] Sukmak, P., S. Horpibulsuk, S.-L. Shen, P. Chindaprasirt and C. Suksiripattanapong, "Factors influencing strength development in clay-fly ash geopolymer." Construction and Building Materials 47, 1125-1136 (2013).

[4] Turner, L. K. and F. G. Collins, "Carbon dioxide equivalent (CO2-e) emissions: A comparison between geopolymer and OPC cement concrete" Construction and Building Materials 43, 125-130 (2013).

[5] A. Palomo, M. W. G., M.T. Blanco., "Alkali-activated fly ashes A cement for the future" Cement and Concrete Research 29, 1323-1329 (1999).

[6] Ángel Palomo, A. F.-J., Cecilio López-Hombrados, José Luis Lleyda, "Railway sleepers made of alkali activated fly ash concrete." Durmientes de hormigón, 75-80 (2007).

[7] Gouny, F., F. Fouchal, P. Maillard and S. Rossignol,
"A geopolymer mortar for wood and earth structures." Construction and Building Materials 36, 188-195 (2012).

[8] Deventer, H. X. J. S. J. V., "The geopolymerisation of alumino-silicate minerals." Int. J. Miner. Process. 59, 247-266 (2000).

[9] MacKenzie, V. F. F. B. K. J. D., "Thermal behavior of inorganic geopolymers and composites derived from sodium polysialte " Materials Research Bulletin 38, 319-331 (2003).

[10] Pacheco-Torgal, F., Z. Abdollahnejad, S. Miraldo, S. Baklouti and Y. Ding. "An overview on the potential of geopolymers for concrete infrastructure rehabilitation." Construction and Building Materials 36, 1053-1058 (2012).

[11] Tomoaki SATOMI, H. K., Hiroshi TAKAHASHI, "Evaluation of Failure Strength Property and Permeability of FiberCement-Stabilized Soil Made of Tsunami Sludge." Journal of JSEM 14(Special Issue), s303-s308 (2014).

[12] Hiroshi TAKAHASHI, H. K. a. T. S., "Study on durability for drying and wetting of cover soil for radiation-contaminated soil made of tsunami sludge." Journal of JSEM 14(Special Issue), 309-313 (2014).

[13] ASTM, "Standard Specification for Coal Fly Ash and Raw or Calcined Natural Pozzolan for Use as a Mineral Admixture in Concrete". C618-12a. West Conshocken, PA, (2012a).

[14] Public Works Research Institute, "Development of Advanced Process and Usage Technique of Construction Sludge." Final Report of Cooperative Research, 77-82 (1997).

[15] Hiroshi Takahashi, T. S., Masato Mori, “CREATION OF ARTIFICIAL GROUND BY RECYCLING TSUNAMI SLUDGE", 15th International Conference on Experimental Mechanics. Porto/Portugal, (2012).

[16] Lizcano, M., A. Gonzalez, S. Basu, K. Lozano, M. Radovic and D. Viehland, "Effects of Water Content and Chemical Composition on Structural Properties of Alkaline Activated Metakaolin-Based Geopolymers." Journal of the American Ceramic Society 95(7), 2169-2177 (2012).

[17] H. RAHIER, B. V. M., "Low-temperature synthesized aluminosilicate glasses: Part II Rheological transformations during low-temperature cure and high-temperature properties of a mode/compound." JOURNAL OF MATERIALS SCIENCE 31, 80-85 (1996).

[18] Valeria F.F. Barbosa, K. J. D. M., Clelio Thaumaturgo, "Synthesis and characterisation of materials based on inorganic polymers of alumina and silica: sodium polysialate polymers." International Journal of Inorganic Materials 2, 309-317 (2000).

[19] Zuhua, Z., Y. Xiao, Z. Huajun and C. Yue, "Role of water in the synthesis of calcined kaolin-based geopolymer." Applied Clay Science 43(2), 218-223 (2009).

[20] Xie, J. and O. Kayali, "Effect of initial water content and curing moisture conditions on the development of fly ashbased geopolymers in heat and ambient temperature." Construction and Building Materials 67, 20-28 (2014). 